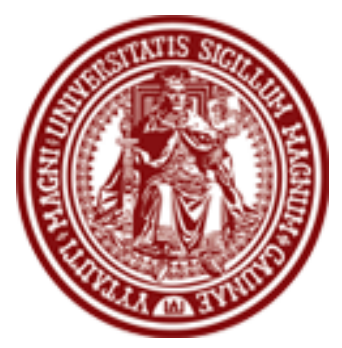

BALTIC JOURNAL OF LAW \& POLITICS

VOLUME 5, NUMBER 2 (2012)

ISSN 2029-0454

http://www.versita.com/science/law/bjlp

Cit.: Baltic Journal of Law \& Politics 5:2 (2012): 27-42

DOI: $10.2478 / \mathrm{v} 10076-012-0009-8$

\title{
INTERPRETERS OF THE CONSTITUTION: THE PROBLEM OF TYPOLOGY
}

\author{
Gediminas Mesonis \\ Professor \\ Faculty of Law, Vytautas Magnus University (Lithuania) \\ Justice of the Constitutional Court of the Republic of Lithuania \\ Contact information \\ Address: Ozeskienès str. 18, Kaunas 44254, Lithuania / \\ Gedimino ave. 36, LT-01104, Vilnius, Lithuania \\ Phone: +370 37751044 \\ E-mail address: g.mesonis@Irkt.It
}

Received: October 23, 2012; reviews: 2; accepted: December 3, 2012.

\section{ABSTRACT}

The significance of the most important legal act-the Constitution-to the social medium is evident. This constituent act of the nation determines the legal, political, moral and social life of the social medium. Therefore, it should come as no surprise that the Constitution-the content of this constituent act-is the object of everybody's attention. The Constitution is interpreted by lawyers, public leaders, state institutions, scholars and individual persons. The article analyses the wide-ranging subjects interpreting the Constitution and presents the types of its interpreters. The three most prominent groups of such subjects can be distinguished as: (i) institutions of constitutional justice, (ii) the scholarly doctrine, and (iii) other subjects. The article discusses the legal, scientific and social value of interpretations of the Constitution formulated by these interpreters. It is held that the most meaningful thing in this typology is distinguishing the interpretations according to the factor of their legal effects. The differing scientific, legal and social value of the interpretations does not deny the factor of the significance of their existence. It is recognised that a large number of interpretations of the content of the Constitution come from an 
immanently related state of discussions taking place in a state under the rule of law and democratic society.

\section{KEYWORDS}

Constitution, interpreters of constitution, constitutional jurisprudence, common sense, cycle of interpretation of constitution 
Democracy is a device that ensures we shall be governed no better than we deserve

Georg Bernard Show

The mission of the constitutional court is to ensure the supremacy of the constitution in system of national system of legal acts ${ }^{1}$

Egidijus Jarašiūnas

\section{INTRODUCTION}

As early as the beginning of the twentieth century Carl Schmitt recognised that the term constitution could be perceived in a number of fairly different ways. He wrote: "[t]he term 'constitution' has various senses. In general meaning of the word, everything, each man and thing, every business and association, is somehow included in a 'constitution', and everything conceivable can have a constitution." 2 However, Thomas Paine's idea that a constitution is the property of a nation, and not of those who exercise the government, coming from The Rights of Man and published in eighteenth century, is nothing short of classic. The question is, however, whether a nation, being the owner of the constitution, is indeed its ultimate interpreter?

The loneliness of the constitution in the legal system stems from its unparalleled power and thus poses serious challenges to its interpreters. At the same time the power and importance of the constitution to the legal system encourages individual efforts aimed at finding out 'what is what' in the constitution. Quite often, however, interpreters fail to give due regard to the fact that complexity of interpretation is preconditioned by the complexity of the constitution itself. Given the supreme legal character of the constitution and its role as the most important catalogue of human rights it seems that the constitution should encourage and welcome such interpretations. The question is, however, which interpretation should be chosen from the vast number of possible options and which interpretation should be considered as the foothold when defending personal rights?

Consequently, one should not be surprised when the concerned entities demonstrate a predilection for considering their own interpretation, which usually and unsurprisingly speaks in their favour, to be the ultimate one. It is also obvious that interpreters of the constitution are fairly different in terms of their intellectual

\footnotetext{
1 Egidijus Jarašiūnas, Démocratie et Liberté: Tension, Dialogue, Confrontation (Bruxelles: Bruylant, 2007), p. 515.

${ }^{2}$ Carl Schmitt, Constitutional Theory (Durham, London: Duke University Press, 2008), p. 59.
} 
abilities, social standing and other aspects, which also impacts the outcomes of interpretation. Alongside the 'free' interpreters, constrained only by their mental ability, there is a range of governmental and other institutions, which, as a part of their remit, must interpret law while ensuring legality and applying legal norms. Every time one comes across challenges with interpretation of the constitution or its norms it becomes clear that J.L. Bergel was right when he wrote that an act of law is not only an act produced by lawmakers, but also an act of interpreters of law, judges and other participants of the legal process. ${ }^{3}$ Given that each and every one of us is very different, it is not surprising that we all have 'our own' constitution. It is for this reason that legal writings provide a large number of typologies which seek to combine interpreters of the constitution into groups. Each such typology is heavily influenced by the methodology and objectives chosen by its author and every such methodology is meaningful in its own special way.

In his Pure Theory of Law Hans Kelsen distinguishes several interpreters: "we have two kinds of interpretations which must be clearly distinguished: interpretation of law by the applying organ, and the interpretation of the law by a private individual and especially by the science of law." ${ }^{4}$ This typology, however, ignores the issue of the legal significance of interpretations. Such methodology would not help to parse the difference of the value of interpretations provided by, for instance, the US Supreme Court in its jurisprudence, a legal writer such as R. Dworkin, or thoughts shared during a press conference by the president of USA. Maybe they are all equally valuable? J. Pelikan, in contrast to Kelsen, is more exhaustive as he refers to as many as four groups of interpreters: a) people b) legal doctrine, c) legal practitioners, d) governmental institutions. ${ }^{5}$ Even though this typology seeks to cover all of the possible interpreters, it fails to address the issue of the legal value of interpretations. Therefore, this typology does not address the issue of legal consequences caused by different interpretations.

One of the Italian sources on constitutional law identifies four groups of interpreters: an interpreter who passed the relevant norm (interpretazione autentica), an official interpreter (interpretazione ufficiale), law enforcement institutions (interpretazione giudiziale) and legal doctrine (interpretazione dottrinale). ${ }^{6}$ This 'Italian' typology differs from the ones mentioned before in that an institution that has passed the relevant norm is also regarded as one of the possible interpreters. Such classification has a legal logic. It is fair to say that the institution that has the power to pass a legal norm may also provide guidelines on

\footnotetext{
3 Jean Louis Bergel, Théorie générale du droit (Paris: Jurisprudence Générale Dalloz, 1999), p. 129.

${ }^{4}$ Hans Kelsen, Pure Theory of Law (Berkeley, Los Angeles: University of California Press, 1967), p. 349.

5 Jaroslav Pelikan, Interpreting the Bible and the Constitution (New Haven, London: Yale University Press, 2004), p. 23-30.

${ }^{6}$ Diritto costituzionale. XVIII Edizione (Napoli: Gruppo Editoriale Esselibri - Simone, 2003), p. 120-121.
} 
its interpretation. It must be stressed, however, that it is not always the case that the position of a lawmaker and official interpreter coincide. The 1948 Constitution of the Republic of Italy envisages that law making is undoubtedly one of the functions of the parliament. ${ }^{7}$ When speaking of the obligation of the constitutional court to ensure the constitutionality of a legal act, the said constitution, however, grants the court the right not only to interpret the constitution, but also to interpret legal acts adopted by the parliament. Similar powers are vested in constitutions of other nations as well. Parliaments are indeed law-making institutions, but the constitutionality of laws passed by them may still be checked. In the course of the process that follows, the institutions of constitutional justice will not only interpret the meaning of the constitution, but also the meaning of laws under review. It is also noteworthy that even constitutional amendments are interpreted by institutions of constitutional review rather than the parliaments that adopted them.

Additionally, it is not unusual to classify interpreters of the constitution based on the quality of provided interpretation. Legal doctrine oftentimes puts an emphasis on the professional abilities of the interpreter and therefore refers to a) professional and b) non-professional interpretations. However, this typology does not explain who the final arbiter is, what its rights are and by what authorisation may the assessment of professionalism of interpretation proceed. How should one identify who has provided a more professional interpretation of the constitution - R. Bellamy, A. Scalia, R. Dworkin or E. Kagan? The question becomes even more relevant when the above-mentioned scholars provide conflicting conclusions. It is obvious that the typology based on the professionalism of interpreters falls apart when several interpretations, 'professional' in their nature but different in their conclusions, are juxtaposed.

\section{INTERPRETERS OF THE CONSTITUTION}

Analysis of typologies of interpreters of the constitution introduced in the scientific environment sometimes brings about fairly controversial results. For example, highly regarded political scientist R. J. Spitzer divides interpreters of the constitution by professions and thus seeks to prove that interpretation of the constitution by lawyers is of questionable value. ${ }^{8}$ Why do lawyers fail to please political scientist R. J. Spitzer? This is because while interpreting constitutions they do not seek objectivity, and because in its essence the legal profession promotes

\footnotetext{
7 Ibid., p. 187-188.

${ }^{8}$ Robert J. Spitzer, Saving the Constitution from Lawyers: How Legal Training and Law Reviews Distort Constitutional Meaning (Cambridge: Cambridge University Press, 2008), p. 129-177.
} 
winning in the legal discourse rather than establishing truth. ${ }^{9}$ At first one is a little curious while reading these 'insights', but gets bored eventually as the author does not provide a conceptual answer to the question. Who should be responsible for the interpretation? And what are those professions, which a priori seek objectivity? Dear author, would you possibly be so kind as to eventually provide a definitive list of moral professions, whose representatives could be charged with the task of interpreting constitutions. Are they political scientists, philosophers, linguists, chemists or physicists? Which of them, in stark contrast with lawyers, are always moral and objective? It follows consequently that by downplaying the role of lawyers as interpreters of the constitution the author also indirectly discards the jurisprudence of the US Supreme Court, because courts are the stronghold of the 'non objective' lawyers who do not seek justice but work to defy their opponents. Having said that lawyers are the worst of interpreters, R. J. Spitzer is quick to share his own understanding of the second amendment of the US Constitution, which should probably be regarded as the "most objective one". When reading these thoughts one can only be sure of one thing, namely, that the freedom of self expression and research indeed is a major value. O. W. Holmes was right - "the prophecies of what the courts will do in fact, and nothing more pretentious, are what I mean by the law. ${ }^{10}$ However, freedom is also characterized by a notion of self-defence, because the right to share any opinion does not automatically turn this opinion into a piece of wisdom.

Evidently, "only a functional constitution is meaningful, i.e. the one which is followed by citizens, officials and state institutions when carrying out their activity. ${ }^{\prime 11}$ Thus, when summarising the mentioned typologies of interpreters of the constitution we may note that anyone who seeks to interpret the constitution must be able to differentiate interpretations based on how compulsory they are. Therefore any typology which reveals the difference between a) official and b) non official interpreters makes sense, because such a typology draws a clear line between those interpretations which legally determine the functionality of the system of legal norms and those which are nothing more than essays on the meaning of the constitution.

Therefore, irrespective of the wisdom of professors and insightfulness of journalists while interpreting constitutions, it must be admitted that the functioning of the legal system is ensured only when one of a number of possible interpretations is granted a compulsory status. To ensure the hierarchy of legal

\footnotetext{
${ }^{9}$ Ibid., p. 60-90.

10 Oliver Wendell Holmes, "The Path of the Law," Harvard Law Review (1897): 460 // http://constitution.org/Irev/owh/path_law.htm (accessed October 17, 2012).

${ }_{11}$ Egidijus Jarašiūnas, "The Control of Constitutionality of Legal Acts and the establishment of the Constitutional Court in Lithuania": 9; in: Constitutional Justice in Lithuania (Vilnius, 2003).
} 
norms, only the mandatory interpretation of the constitution can be important. It is this interpretation which results in a legal reality rather than remaining merely the result of individual efforts. Therefore it could be maintained that any typology identifying official and unofficial interpreters is meaningful, for it reveals which interpretation will result in actual legal consequences and which is merely the expression of freedom of speech and thought. We must also admit, however, that the dichotomous typology which only takes account of the factor of mandatoriness into account could further be developed so as to incorporate features observed in the abundance of official and unofficial interpretations.

Table 1: Typology of the Interpreters of the Constitution

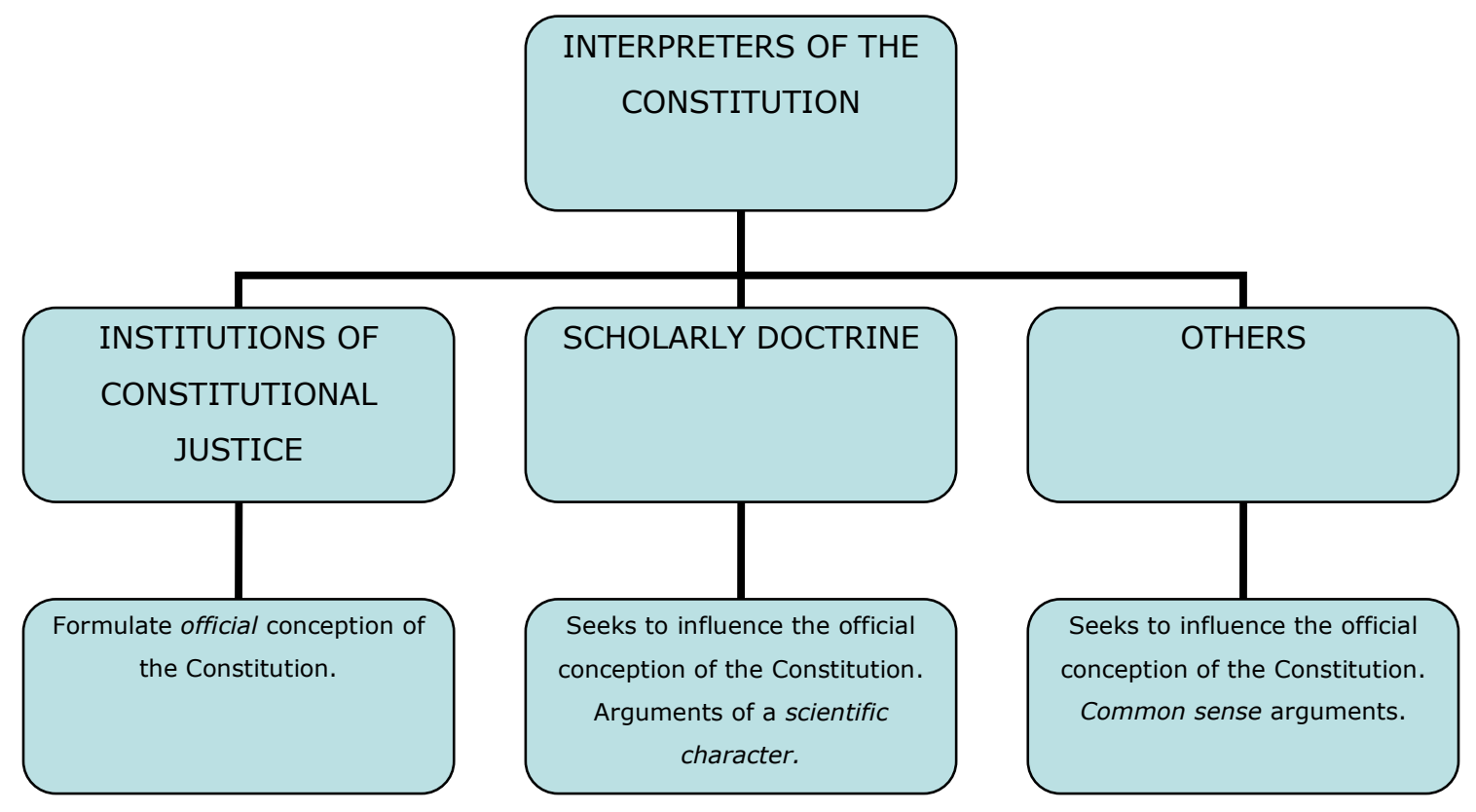

The typology presented in Table 1 not only takes account of the mandatory (or non-mandatory) character of the interpretation, but also places an emphasis on the importance of legal research. This typology is relevant for several reasons. By putting separately the institutions of constitutional justice we are able to avoid meaningless and subjective discussions on the degree of 'science' in their interpretation. ${ }^{12}$ An official conception of the constitution formulated by institutions of constitutional justice is mandatory to everyone and the official interpretation is a source of legality for the whole system of legal norms.

Sitting next to the official constitutional jurisprudence, the scholarly doctrine occupies an exceptional position in the typology of interpreters of the constitution. It is the scholarly interpreters who, by drawing on the freedom of research and

12 Gediminas Mesonis, Konstitucijos interpretavimo metodologiniai pagrindai (Vilnius: Registru centras, 2010), p. 66-68. 
applying a whole range of research instruments, formulate a scholarly and conceptually persuasive position as to what an ideal interpretation of the constitution should be. Scholars are free to make judgements and share their opinions. However, they do not have powers to change the official interpretation of the constitution. Scholarly doctrine must be granted the status of a special interpreter, as quite often its arguments and proposed interpretations sooner or later are incorporated in the constitutional jurisprudence. One might also divide the functions of the scholarly doctrine into perspective and retrospective. ${ }^{13}$ (Table 2 )

Table 2: Typology of Functions of the Scholarly Doctrine

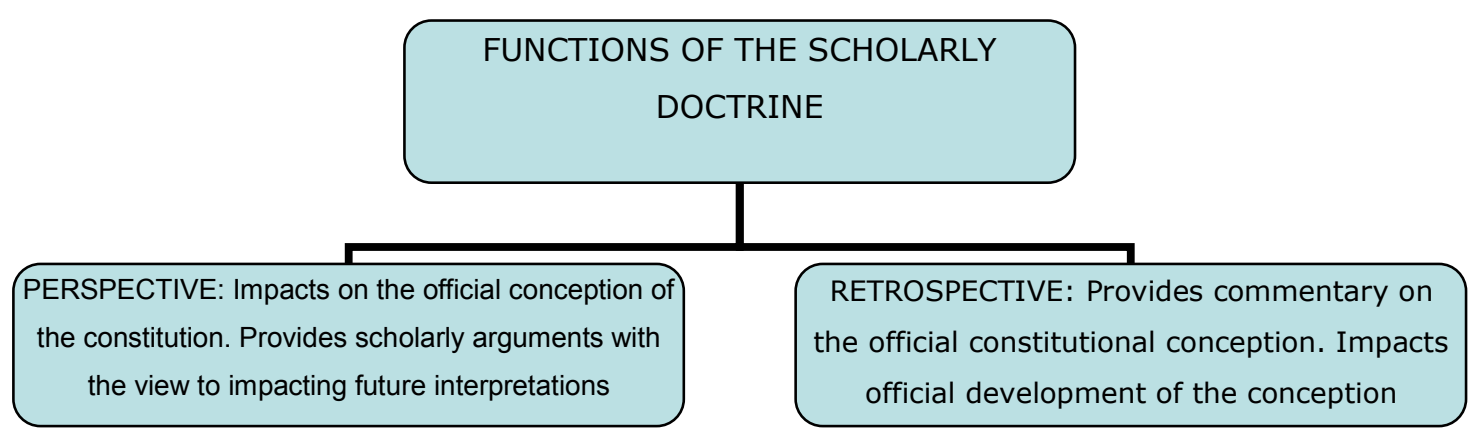

Steiner perceives this issue in a similar manner by distinguishing a) interpretative function and $b$ ) the function of scholarly leadership. ${ }^{14}$ Even though the scholarly doctrine (in its broad sense) is not homogenous, multifaceted and quite often fragmented, one cannot underestimate its relevance in the process of formation of the official constitutional jurisprudence. First, scholarly arguments (or even the whole system of arguments) are a powerful source of argumentation in their own right and the official interpreter must become familiar with them. It is understandable that by applying methods of scientific cognition oftentimes the scholarly doctrine formulates conclusions which, because of their logical grounding and systemic approach to the problem, nearly do not leave any room for alternative conclusions. Therefore, quite often the official constitutional jurisprudence merely repeats some arguments and conclusions already formulated by scholars. Thus, scientific research seeks to formulate suggestions (variants of interpretation of the constitution) and propose them, i.e. to envisage the future development of the constitutional jurisprudence. This function of science is referred to as perspective. Constitutional scholarly jurisprudence must make it known what the ideal conception of the constitution is and what it should be like.

\footnotetext{
13 Ibid., p. 67.

${ }^{14}$ Eva Steiner, French Legal Method (Oxford: Oxford University Press, 2003), p. 180-181.
} 
The importance of scholarly arguments does not fade away in those situations which deal with the analysis of the already existing (i.e. official) constitutional version. It may seem that the significance of post factum scholarly analysis is lower but it is not so. First of all, it is at those times that the scholarly doctrine becomes the single most professional entity able to provide its evaluation. The scholarly doctrine is in the position to provide commentary on the decisions of institutions of constitutional review and must do so by inquiring into the matter of its arguments and conclusions. Even though in post factum situations the scholarly doctrine is unable to change legal consequences emerging from the official version, it does pave the way for a possible change in the interpretation of the constitution, by shaping the scholarly outlook. A doctrinal analysis of constitutional jurisprudence serves as the intellectual basis for further development and change. Irrespective of its quality scholarly doctrine is indeed valuable. Even the 'know how' demonstrated by R. J. Spitzer that the constitution should not be interpreted by lawyers is valuable in that it encourages a scholarly debate, which inevitably reaches a conclusion that this idea does not contain any knows or how's. In scholarly discussions arguments are presented and conceptually based conclusions are drawn but only the court has the powers necessary to preserve the values of constitutionalism, because other alternatives are unavailable.

Not only is the scholarly doctrine persuasive because of the systemic cognition of the problem but also because arguments for or against are presented by respected figures in the relevant field. To be more precise, scholars frequently bolster scholarly arguments with the power of their authority. Reference to respected figures is typical of the Roman, German and Anglo-Saxon system of law, where outstanding scholarly figures are not only responsible for the contents of obiter dicta or ratio decidendi of some court decisions but also for tendencies in the development of law. ${ }^{15}$ However, choosing the easiest way, relying on respected scholars rather than seeking a logical system of arguments, is a typical course of action in other areas as well. It is particularly so in the case of common sense type of arguments and individual interpretations of the constitution.

\section{COMMON SENSE IS NOT SO COMMON}

The common sense type of argument(s) is a specific system of argumentation. In Table 3 we referred to other interpreters and also pointed out that the quality of interpretation provided by these interpreters reflects the limitations of common sense. Common sense was first used by Scottish philosopher

15 John Hynes Farrar and Anthony M. Dugdale, Introduction to Legal Method (London: Sweet \& Maxwell, 1990), p. 200-210. 
T. Reid (1710-1796) in his work An Inquiry Into the Human Mind on the Principles of Common Sense (1764). In the epoch of Reid common sense seems to have held a respectable position as it was juxtaposed with philosophical paradoxicality and scepticism. However, it was not long before disappointment with the concept crept in. Already Voltaire was quite sceptical about the possibilities to probe questions deeply by employing this method and said that 'common sense is not so common'.

What are the qualitative criteria of the common sense approach? To answer the question we will perform a comparative analysis of features of the common sense doctrine and scholarly arguments. The difference between common sense and scholarly arguments lies in the fact that even logically grounded common sense arguments are easily defeated by employing a thorough analysis of the issue. Due to the limitations of the common sense approach such analysis is often omitted. It is the common sense approach which builds the illusion that questions of constitutional justice are easy and answers are 'obvious'. As a university professor lecturing in constitutional law, time and again I have seen students and other individuals, even those holding a degree in law, coming up with answers in the most complicated areas of constitutional law within a matter of seconds. When questioned on the issues of abortion or euthanasia laymen are quick to jump to conclusions. Obviously, however, a more thorough analysis of the legal problem reveals that common sense arguments are often superficial. In his classical book The Rules of Sociological Method, Emile Durkheim proves an obvious but important fact in conceptual terms, namely, that men tend to solve the most intricate questions in one fell swoop and usually find the 'right solution' by employing syllogisms and artificial observation. The author goes on to prove his point with an example from criminality. Based on the fact that crime is a disgusting and despicable phenomenon, common sense erroneously decides that it should become extinct altogether. ${ }^{16}$ Meanwhile the science of criminology draws a completely opposite conclusion, maintaining that criminality will not leave any country untouched, including Luxembourg with a \$100.000 rate per capita. Thomas Kuhn notes something more, writing that in the partially circular arguments that regularly result, each paradigm will be shown to satisfy more or less the criteria that it dictates for itself and to fall short of a few of those dictated by its opponent. ${ }^{17}$ The author makes a very good point about the fact that rarely will a man be able to critically inquire into interpretations that express his own intentions. Artificiality is

16 Emile Durkheim, Les Règles de la méthode sociologique (Paris: Presses Universitaires de France, 2007), p. 6-77.

17 Thomas Samuel Kuhn, The Structure of Scientific Revolutions (Chicago: University of Chicago Press, 1996), p. 119. 
easily observed when we come across interpretations of the constitution at the common sense level.

Therefore interpreters providing common sense interpretations only have one goal in mind, namely, to convince themselves. To attain to this goal, the level of logic, which the interpreter is able to provide himself, is always enough. It should be stressed that not only are conclusions at the common sense level only partially logical, but also the fact that the logical limitations are determined by inherent possibilities of common sense. While trying to solve an interpretational issue the interpreter does not seek to conceptually inquire into the problem; instead, he treats an artificial objective as a conceptual one. Therefore, artificiality is a trait of both arguments and conclusions of the common sense approach. However, common sense arguments cannot be dismissed as utterly pointless. Frequently, poor quality of arguments is determined by objective circumstances, such as the level of legal consciousness, intellectual and cognitive abilities. More than that, A. Sajó maintains that human sentiments alone are powerful enough to exercise their grip over the interpreter. He writes: "[m]oral sentiments served as centers of gravity in the formation of constitutional sentiments. ${ }^{18}$ Therefore, rising above the common sense level, maintaining the ability to discard subjectivity, nonprofessionalism, emotions, personal interests is a major challenge. It takes time and other factors; therefore, even professional experts quite often rely on common sense arguments if they are unable to move to a higher level than common sense.

Common sense arguments are also insidious because they are difficult to tell from the scholarly ones when they withstand the test of logical consistency. However, they cannot be treated as scholarly arguments, which are different. While aiming to be regarded as an expert's voice on certain issues, not only scholarly arguments follow clear logical reasoning and have an empirical basis (which is very typical of common sense arguments) but are founded on a systemic analysis of a constitutional issue at stake. The illusion of simplicity within the social sciences brings the idea that participation in a constitutional discourse nearly does not require any special preparation. It is in this type of discourse that "we can quite often notice attempts to juxtapose the concepts of constitution and democracy, the rule of law on the basis of subjectively perceived slogans of 'democracy' or 'real national (or public) interest." ${ }^{\prime 19}$ It is obvious that such views are dominated by common sense arguments. They are easily defeated by the scholarly doctrine and activity of constitutional justice. Authors of common sense 'arguments' rarely shoot

\footnotetext{
${ }^{18}$ András Sajó, Constitutional sentiments (New Haven \& London: Yale University Press, 2011), p. 12.

${ }^{19}$ Gediminas Mesonis, "Tomaš Garrigue Masaryk and Mykolas Römeris: Two figures, Two Approaches to the State and the Constitution," Acta Universitatis Carolinae. Iuridica No. 2. (Praha, Univerzita Karlova v Praze, 2010): 56.
} 
for objectivity. Quite often their objectives are permeated by subjective or political interest or personal motivation. However, politics is an important business, which has its own objectives and modus operandi, and it is not unnatural that even the 'efforts' of politicians should be respected. The conclusions drawn by institutions of constitutional justice and the scholarly doctrine are different from common sense approach in that they follow a logical system, therefore even when one does not agree with them, it is not easy to prove otherwise.

The quality of interpretation depends on how well the interpreter is acquainted with the problem of constitutional justice at the systemic level. However, no one could say with absolute certainty that common sense arguments and conclusions that follow will always contradict the scholarly doctrine or the ones formulated by the official interpreter. However, even when these coincide, scholarly conclusions are more valuable as they rest on stronger qualitative and quantitative arguments. On the other hand, it must also be observed that even though scholarly doctrine is more 'professional' and able to elegantly defeat common sense arguments it is unable to come up with a unified conclusion. It is so because of the scholarly pluralism and the resulting considerable fragmentation. Because of this, not only the public at large but also revered scholars sometimes see the constitution as an interpretative enigma. It is obvious that the 'enigmatic' nature of constitutional interpretation lies in the fact that from a scholarly perspective all interpretations are equal in that they do not result in any actual legal consequences. The destiny and significance of these subjective interpretations are at the 'mercy' of the official interpreter. It is the will of the official interpreter that gives the 'interpretational enigma' its jurisprudential form and makes it the source of actual legal consequences. In this respect J. M. Pollock is quite right to note that justices are the final arbiters and interpreters of law. ${ }^{20}$ It is so, because the interpretation formulated by the court or by an institution of constitutional justice (to be more precise) is obligatory to everybody as a source of law.

\section{CYCLE OF INTERPRETATION OF THE CONSTITUTION}

"We have a constitutional text", but "we do not disagree about which inscriptions comprise that text." ${ }^{21}$ R. Alexy recognised the fact that "everyone who can speak may take part in discourse" and "everyone may problematize any assertion", "everyone may introduce any assertion into the discourse, "everyone

20 Joycelyn M. Pollock, Ethical Dilemmas and Decisions in Criminal Justine (Wadsworth, Cengage Learning, 2007), p. 378.

${ }^{21}$ Ronald Dworkin, Justice in Robes (Cambridge, Massachusetts, London: The Belknap Press of Harvard University Press, 2006), p. 120. 
may express his or her attitudes, wishes and needs."22 Yes, society is continuously exposed to a wide range of interpretations, which differ in their scholarly and legal value. Each of them has its place and significance. Irrespective of the country, the process of understanding the constitution has several typical stages. The cycle of interpretation of constitution is an immanent discussion about the contents of the constitution. (Table 3)

Table 3: the Cycle of Interpretation of Constitution
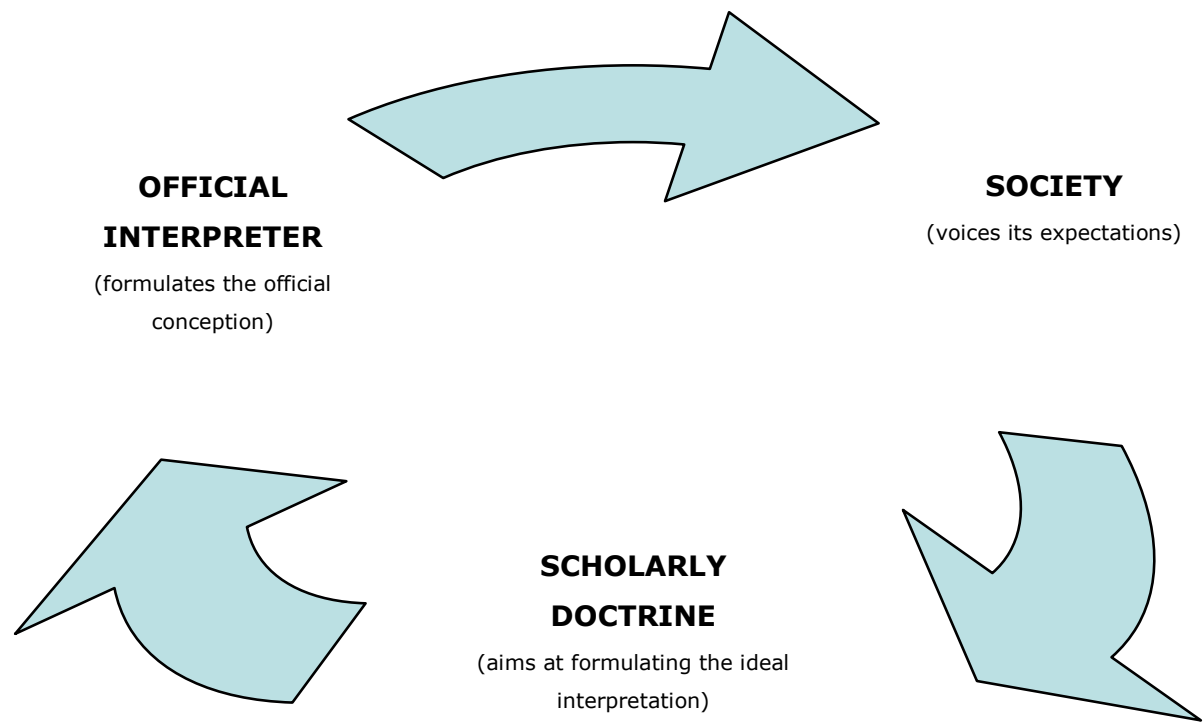

The cycle of interpretation of the constitution is an inherent situation of the society, where the meaning of the constitution, which is an object of a permanent analysis, is continuously interpreted with the view to revealing it. The cycle of interpretation of the constitution is a continuous movement from expectations of the society expressed at the common sense level towards scholarly conclusions and a systemic understanding of the issue and finally from a scholarly doctrine towards the official conception. ${ }^{23}$ Official conception of the constitution is then analysed in the society, remarks and expectations are shared and are again analysed by the official interpreter of the constitution.

Thus, the interpretation of the constitution is not (probably not only) the condition of its application (so, it is not "supplement" to the constitutional document), but a process, which guarantees harmony between the stability of fundamental constitutional provisions in the continuous development of the

\footnotetext{
22 Robert Alexy, A Theory of Legal Argumentation. The Theory of Rational Discourse as Theory of Legal Justification (Oxford: Clarendon Press, 1989), p. 193.

${ }^{23}$ Gediminas Mesonis, supra note 12, p. 73.
} 
constitutional regulation and dynamics of the constitution, understood as its capability to correspond to the changing social and political environment. ${ }^{24}$

All of the composite parts of the cycle of interpretation of the constitution make it possible for the principle of the rule of law to exist in a democratic society, because "we might borrow from the constitutional text to help remind us of our past political struggles or inspire us to take on new national projects". ${ }^{25}$

\section{CONCLUSIONS}

The official interpreter of the constitution is an institution, which has authorities of a constitutional character, and no other. The constitution sets the right and the duty to the constitutional justice institution to interpret constitution, i.e. to formulate constitutional jurisprudence (official version of the concept of constitution).

Constitutional jurisprudence being formulated by the constitutional justice institution is the only source that is the basis to guarantee the legitimacy of legal norms in the system. Official interpretation is obligatory, i.e. it is not dispositive, and, on the contrary, it is an imperative form of law. It must be accepted and followed by every subject of legal relations.

Providences of scholarly doctrine, unlike official constitutional jurisprudence having no juridical obligation guarantees, can only make influence on official interpreter with validity of scientific arguments and hope for it to become an official one someday. Subjectivity of scholarly doctrine and its dispositive character does not negate its significance in the legal norms constitutionality insurance process. Systemic-expert knowledge of the problem characterizes arguments and conclusions of scholarly doctrine. Scholarly doctrine analyzing official interpretation and proposing its estimations performs important retrospective and perspective functions.

The retrospective function of scholarly doctrine expresses itself in its right to analyze the present official version of the concept of a constitution, and the search for its estimation criteria in order to improve or change it. The conceptual value of the perspective function of scholarly doctrine expresses itself in its objective possibility to propose possible interpretative models for the future. This is the way creating influence on an official interpreter, on his choice in formulating official a

24 Egidijus Kūris, "The Constitutional Court and Interpretation of the Constitution": 205; in: Constitutional Justice in Lithuania (Vilnius, 2003).

25 Keith E. Whittington, "How to Read the Constitution: Self-Government and the Jurisprudence of Originalism," The Heritage Foundation 5 (2006) //

http://www.heritage.org/research/reports/2006/05/how-to-read-the-constitution-self-government-andthe-jurisprudence-of-originalism (accessed October 17, 2012). 
version of the concept of constitution. Official and scholarly doctrine make up a very small part of the interpretation introduced to the society.

Common sense limitation mostly is typical for society's own (i.e. social) interpretations. Although these interpretations are characterized by logical consistency, the problems are being analyzed superficially, and the method of the object's systemic cognition is not being used. Therefore interpretations of common sense level can be popular in the society, but they would be conceptually easily defeated with methods and arguments of scientific and official constitutional jurisprudence. It should be noted that value of interpretations of the common sense level is determined by the freedom of speech and self-expression. Through the common sense level interpretations society expresses its expectations; therefore creators of scientific as well as of constitutional jurisprudence should consider it. All constitutional interpretations (official, scientific, common sense level) are the result of society's intellectual and structural realities, thus their existence is inevitable.

The cycle of interpretation of the constitution is an immanent system of the constitution's content perception that already exists in the society: from the superficiality of common sense to scientific arguments and systematic cognition of the problem and, finally, from the scientific to official constitutional jurisprudence.

\section{BIBLIOGRAPHY}

1. Alexy, Robert. A Theory of Legal Argumentation. The Theory of Rational Discourse as Theory of Legal Justification. Oxford: Clarendon Press, 1989.

2. Bergel, Jean Louis. Théorie générale du droit. Paris: Jurisprudence Générale Dalloz, 1999.

3. Diritto costituzionale. XVIII Edizione. Napoli: Gruppo Editoriale Esselibri Simone, 2003.

4. Durkheim, Emile. Les Règles de la méthode sociologique. Paris: Presses Universitaires de France, 2007.

5. Dworkin, Ronald. Justice in Robes. Cambridge, Massachusetts, London: The Belknap Press of Harvard University Press, 2006.

6. Farrar, John Hynes, and Anthony M. Dugdale. Introduction to Legal Method. London: Sweet \& Maxwell, 1990.

7. Holmes, Oliver Wendell. "The Path of the Law." Harvard Law Review (1897) // http://constitution.org/Irev/owh/path_law.htm (accessed October 17, 2012).

8. Jarašiūnas, Egidijus. Démocratie et Liberté: Tension, Dialogue, Confrontation. Bruxelles: Bruylant, 2007. 
9. Jarašiūnas, Egidijus. "The Control of Constitutionality of Legal Acts and the establishment of the Constitutional Court in Lithuania": 3-39. In: Constitutional Justice in Lithuania. Vilnius, 2003.

10. Kelsen, Hans. Pure Theory of Law. Berkeley, Los Angeles: University of California Press, 1967.

11. Kuhn, Thomas Samuel. The Structure of Scientific Revolutions. Chicago: University of Chicago Press, 1996.

12. Kūris, Egidijus. "The Constitutional Court and Interpretation of the Constitution": 205-321. In: Constitutional Justice in Lithuania. Vilnius, 2003.

13. Mesonis, Gediminas. Konstitucijos interpretavimo metodologiniai pagrindai. Vilnius: Registru centras, 2010.

14. Mesonis, Gediminas. "Tomaš Garrigue Masaryk and Mykolas Römeris: Two figures, Two Approaches to the State and the Constitution." Acta Universitatis Carolinae. Iuridica No. 2 (Praha, Univerzita Karlova v Praze, 2010): 37-61.

15. Pelikan, Jaroslav. Interpreting the Bible and the Constitution. New Haven, London: Yale University Press, 2004.

16. Pollock, Joycelyn M. Ethical Dilemmas and Decisions in Criminal Justine. Wadsworth, Cengage Learning, 2007.

17. Sajó, András. Constitutional Sentiments. New Haven \& London: Yale University Press, 2011.

18. Schmitt, Carl. Constitutional Theory. Durham, London: Duke University Press, 2008.

19. Spitzer, Robert J. Saving the Constitution from Lawyers: How Legal Training and Law Reviews Distort Constitutional Meaning. Cambridge: Cambridge University Press, 2008.

20. Steiner, Eva. French Legal Method. Oxford: Oxford University Press, 2003.

21. Whittington, Keith E. "How to Read the Constitution: Self-Government and the Jurisprudence of Originalism." The Heritage Foundation 5 (2006) // http://www. heritage.org/research/reports/2006/05/how-to-read-theconstitution-self-government-and-the-jurisprudence-of-originalism (accessed October 17, 2012). 